\title{
Odwołanie do przeszłości w architekturze sakralnej państwa krzyżackiego
} Doniższy tekst ma zasygnalizować problem obecności elementów gene-
tycznie powiązanych z tradycją romańską obecnych w sporej grupie dzieł sakralnej architektury krzyżackiej. Tytułowe „odwołanie do przeszłości” rozumiem umownie - jako dualizm form progresywnych i regresywnych, które można postrzegać w kontekście świadomego wyboru określonej opcji estetyczno artystycznej. Czy była ona na tyle silna i reprezentatywna, że można zaliczyć ja do cech kwantytatywnych architektury krzyżackiej? I przede wszystkim, czy za architektoniczną retrospekcją stoi myślenie o ideowej, historycznej funkcji tych odwołań? Poniżej przyczynek do tak szeroko postawionego pytania.

Zagadnienie było sygnalizowane w literaturze, głównie w opracowaniach monograficznych, gdy pisząc o źródłowych koneksjach, przywoływano dzieła i tendencje z okresu romanizmu. Wśród budowli sakralnych wątek ten pojawił się w odniesieniu do katedr w Chełmży, Kwidzynie i Królewcu oraz szeregu realizacji parafialnych. Przywołam przykładowo kościoły: św. Mikołaja w Chełmży, NMP w Chełmnie, św. Mikołaja w Grudziądzu, św. Katarzyny w Brodnicy, św. Jana w Toruniu, św. Jakuba w Toruniu, czyli we wszystkich znaczniejszych ośrodkach diecezji chełmińskiej. Wśród autorów, którzy dostrzegali element romańskiej archaizacji w wymienionych obiektach, wymienić należy Teresę Mroczko i odpowiednie akapity opracowania o architekturze ziemi chełmińskiej oraz wielu badaczy, którzy jej wnioski 
powtarzali lub rozwijali ${ }^{1}$. Jednostkowo wątek ten przewija się w pracach M. Kutznera (Toruń), L. Krantz-Domasłowskiej (Kwidzyn, Toruń), E. Pileckiej (Toruń) oraz A. Soćki (Chełmno) ${ }^{2}$. Ostatni autor dostrzegł ponadto szerszy wymiar zjawiska. W artykule z 2011 roku przywołując architektoniczne przykłady, masyw wieżowy w Chełmnie, dwupoziomową kaplicę na zamku biskupów warmińskich w Braniewie, dyspozycję przestrzenną chóru katedry w Kwidzynie oraz grupę kościołów pseudobazylikowych (Dzierzgoń, Bartoszyce i Nowe Miasto Lubawskie), zadał pytanie o romańskie tradycje w architekturze państwa krzyżackiego ${ }^{3}$. W większości opracowań zagadnienie to było przywoływane jedynie w kontekście poszukiwań ciągów genetycznych i analogii formalnych, ale ich liczba potwierdza słuszność postawienia pytania problemowego. A jak wielowymiarowe może być zagadnienie architektonicznych odwołań do przeszłości, pokazuje między innymi ostatnia praca P. Gryglewskiego 4 .

Dla zobrazowania tendencji retrospektywnych przywołam kategorię typologiczna, pseudobazylikową dyspozycję przestrzeni korpusu nawowego, a także tradycję romańskich masywów wieżowych oraz obecność empor jako wydzielonych wnętrz dla krzyżackich hierarchów.

1 T. Mroczko, Architektura gotycka na ziemi chetminskiej, Warszawa 1980.

2 M. Kutzner, Lubecki styl architektury gotyckiego kościola św. Jakuba w Toruniu, [w:] S 2 tuka Torunia i Ziemi Chetminskiej 1233-1815, red. J. Poklewski, Warszawa 1986, s. 55-77; L. Krantz-Domasłowska, Katedra w Kwidzynie, Torun 1999; L. Krantz-Domasłowska, J. Domasłowski, Kościót św. Jakuba w Toruniu, Torun 2001, s. 54-61; L. Krantz-Domasłowska, Architektura, [w:] Basylika katedralna swnietych Janów, red. M. Biskup, Toruń 2003, s. 54-108, m.in. s. 99-101; E. Pilecka, Kościót p.w. sw. Jana Chraciciela $i$ sw. Jana Ewangelisty w Toruniu w okresie średniowiecza jako wizualizacja śmiadomości spotecznej, [w:] Drieje i skarby kościoła Świetojańskiego w Toruniu, red. K. Kluczwajd, s. 119-176; A. Soćko, Pierwowźór masywu wieżowego fary chetmińskiej, „Artium Quaestiones”, t. XVI, 2005, s. 5-34. Autor omawia także wymienione obiekty w syntetycznej pracy Układy emporowe w architekturze państwa krazyżackiego, Warszawa 2005.

3 A. Soćko, Romańskie tradycje w gotyckiej architekturze państwa krayżackiego, [w:] Polska $i$ Europa w średniowieçu. Przemiany strukturalne. Przedmioty $i$ przemiany w badaniach bistorycznych, red. M. Adamczewski, Warszawa 2011, s. 95-105; idem, Kościót sw. Jana Ewangelisty w Bartosaycach na tle średniowiecznej architektury sakralnej w Prusach, „Studia Zamkowe”, 4, 2012, s. 217-228.

4 P. Gryglewski, De Sacra Antiquitete. Odwołania do przesz̨łości w polskiej architekturze sakeralnej XVI wieku, Warszawa 2012. 
$\mathrm{Na}$ terenie państwa krzyżackiego układy pseudobazylikowe były popularnym rozwiązaniem (kilkanaście kościołów) ${ }^{5}$. Większość założeń datowana jest na wiek XIV, przy czym część przykładów to korpusy niejednorodne, gdzie układ pseudobazylikowy stanowił tylko jedną z faz, co skłania do indywidualnego badania historii budowlanej każdego z obiektów ${ }^{6}$. Jednak świadomość, że sposób kształtowania korpusu z nawą główną wyższą od bocznych, ale pozbawioną źródła światła stosowany był już od X wieku, obejmując swoim zasięgiem w kolejnych stuleciach romańską Francję, Hiszpanię i Włochy, aby w XIII i XIV zyskać popularność na terenie Niemiec, umacnia w przekonaniu, że wybór tej opcji przestrzennej w kościołach pruskich był świadomą decyzją podyktowaną względami pragmatycznymi („,bezpieczeństwo” konstrukcji, ekonomia), ale nie tylko. Jednorodność bryły przy jednoczesnej hierarchizacji wnętrza oraz możliwości różnorodnego kształtowania ściany międzynawowej to były walory natury estetyczno-artystycznej. Zasadniczo dominuje w literaturze tendencja do klasyfikowania układów pseudobazylikowych jako stylistycznie zapóźnionych, „gorszych sióstr” klasycznej bazyliki. I wśród przykładów krzyżackich takie mamy, chociażby przywołane przez A. Soćkę kościoły w Dzierzgoniu, Bartoszycach, Nowym Mieście Lubawskim, lecz ich anachronizm polegał nie tyle na wprowadzeniu koncepcji pseudobazyliki z prześwitami na kondygnację strychowa, ale z jednoczesnej rezygnacji ze sklepień. (il. 1) Była to podstawowa przyczyna ich późniejszej przebudowy ${ }^{7}$. Natomiast katedra w Kwidzynie, przynależąc do grupy pseudobazylik blendowych lub jak chce E. Kwapisz

5 L. Krantz-Domasłowska, Katedra..., s. 59-80; L. Krantz-Domasłowska, Pseudobasilikea - eine selbständige oder bybride Form?, [w:] Kościót i sztuka pobrzeża Battyku, red. M. Woźniak, Toruń 1998, s. 77-102.

6 E. Milczarska, Gotycki kościót parafialny w Moragu. Fasy budowy i datowanie, „Kwartalnik Architektury i Urbanistyki”, 28, 1983, z. 2, s. 119-142; E. Korpysz, Gotycki kościót w Dzierzgoniu, [w:] Studia nad architektura Gdanska i Pomorza, red. A. Grzybkowski, Warszawa 2004, s. 9-38; A. Soćko, Kościót sw. Jana Ewangelisty w Bartoszycach...

Kościół w Nowym Mieście Lubawskim (diecezja chełmińska) przebudowano na bazylikę już w 3. ćw. XIV wieku. Korpus kościoła w Bartoszycach (diecezja warmińska), który uzyskał swoja pierwotną formę w latach 1360-1380, nadbudowano i zasklepiono w 1487 (E. Korpysz za T. Mroczko, s. 34) lub przed poł. XIV w., aby następnie nadbudować chór ok. 1400 oraz korpus wieży w 1. poł XV w. (A. Soćko, s. 220). W Dzierzgoniu (diecezja pomezańska) I kościół salowy z 4. ćw. XIII w.; II rozbudowa o kryptę, 2. dziesięciolecie XIV w.; III korpus 2. ćw. XIV w.; IV podwyższenie chóru (E. Korpysz, s. 32). 
prześwitowych, prezentuje koncepcję formalnie spójną i przemyślaną którą można zaklasyfikować jako świadomy wybór romanizującej stylistyki genetycznie konweniującej z układem dwupoziomowej części wschodniej, a jednocześnie budującej wizualny kontrast z jasną doświetloną częścią górnego chóru. (il. 2) Pseudobazylikowy korpus katedry w Królewcu jest już wyborem wtórnym, gdzie decyzja o przesklepieniu wnętrza wpłynęła na rezygnację z klasycznego układu bazylikowego. Najliczniej reprezentowana była ta forma przestrzenna na terenie diecezji chełmińskiej, chociaż i tu najstarszy przykład, korpus kościoła Franciszkanów w Chełmnie oraz fara w Chełmży są realizacjami wtórnymi, będąc konsekwencja przekształceń wcześniejszych układów halowych ${ }^{8}$. Jedynie kościół św. Mikołaja w Grudziądzu zachował pierwotna dyspozycję wnętrza z około połowy XIV wieku, prezentując gładkie ściany międzynawowe wsparte na ośmiobocznych filarach, gdzie podobnie jak w Kwidzynie wzmocniono dynamikę przestrzeni poprzez kontrast z jasnym wielobocznym chórem9. (il. 3) Należy wspomnieć jeszcze o dwóch przykładach toruńskich. Wyodrębniana (ze znakiem zapytania) faza pseudobazylikowego korpusu kościoła św. Jana (III), będąca efektem odbudowy świątyni po pożarze miasta w 1351 roku, zyskała dodatkowy kontrargument. Dotychczas kontrowersje dotyczyły zakresu zniszczeń i zmian, które wprowadzono we wnętrzu w 2. połowie XIV wieku. Jedna z hipotez (C. Steinbrecht, T. Mroczko) zakładała nie tylko odbudowę części zachodniej, ale także przebudowę korpusu halowego na pseudobazylikowy, przy czym jedynym zachowanym obecnie materialnym śladem miał być otwór na ścianie tęczowej służący jako łącznik z nową kondygnacją podda-

8 T. Mroczko, op. cit., s. 211. Kościół franciszkanów w Chełmnie pw. św. Jakuba i św. Mikołaja zdaniem Autorki uzyskał formę pseudobazyliki na początku XIV w. w wyniku modyfikacji planowanego korpusu halowego; J. Heise, Die Bau- und Kunstdenkmäler der Provinz. Westpeussen, Bd. 2, H.10, Kreis Löbau, Danzig 1895, s. 69, zakładał, że kościół od początku, 2. poł. XIII w., miał formę pseudobazylikowa; L. Krantz-Domasłowska, Pseudobasilika..., s. 81, 82. Kościół św. Mikołaja w Chełmży kształt pseudobazylikowego korpusu uzyskał w 1. lub 2. ćw. XIV w. B. Sławiński, Gotycka architektura kościoła parafialnego pw. sw. Mikotaja w Chetmisy, „Acta Universitatis Nicolai Copernici, Zabytkoznawstwo i Konserwatorstwo", XXVII, Toruń 1996, s. 25-43.

9 T. Mroczko, op. cit., s. 217-219, 224; A. Soćko, Układy..., s. 24-27. 
sza nawy środkowej ${ }^{10}$. Wyniki zakończonych ostatnio prac konserwatorskich nie potwierdzają odrębnego etapu budowlanego określanego jako III korpus nawowy, natomiast pozwalają zaproponować konkurencyjna do utrwalonej w literaturze rekonstrukcję kształtu części zachodniej II budowli jako wieży z bocznymi aneksami ${ }^{11}$. „Wyciszenie” tezy o istnieniu psudobazylikalnej fazy w historii budowlanej kościoła św. Jana równoważy nowy wątek w dziejach nowomiejskiej fary św. Jakuba. A. Konieczny zaproponował ostatnio rekonstrukcję korpusu nawowego, jaki miał pierwotnie odpowiadać zrealizowanej już części wschodniej w formie pseudobazyliki ${ }^{12}$. Swoją hipotezę oparł głównie na obserwacjach struktury architektonicznej, w tym śladów zachowanych na kondygnacji strychów. Projekt ten nigdy nie został zrealizowany, uległ bowiem modyfikacji w trakcie prac przy korpusie. Jednak przyjęcie takiej koncepcji diametralnie zmienia optykę na ukończoną ostatecznie formę trójnawowego bazylikowego wnętrza. Przede wszystkim w nowym świetle stawia architekta, który swój całościowy projekt oparłby na całkowitym przeciwieństwie form, stylu, estetycznych doznań i genetycznych powiązań chóru i korpusu. Kontrast między obu częściami kościoła jest czytelny także obecnie, ale jego skala byłaby zwielokrotniona. Problem pozostaje otwarty.

Przytoczone powyżej obiekty z terenu diecezji chełmińskiej wpisują się w zbliżony horyzont czasowy połowy XIV wieku oraz, co istotne, ich lokalizacja dotyczy ważnych ośrodków administracji krzyżackiej. Jednak nie

10 Cała datacja i rekonstrukcje bazują na źródle z 1361 r. zawierającym zapis 200 grzywien na odbudowę wieży i kościoła. C. Steinbrecht (1885) oraz T. Mroczko (1980) przyjęli, że odbudowa objęła wieżę i korpus; J. Heise (1889) tylko wieżę i sklepienia, a A. Semrau (1913) ograniczył prace do części zachodniej. L. Krantz-Domasłowska, Architektura..., s. 82-87.

11 Zasugerowane wnioski znalazły się w tekście M. Dobrzyńskiej-Musiela, I. Brzostowskiej, „Cqasu jusz nie bedzie wiecy - Robcie dobrze poki czas macie”. Historia najnows zej konserwacji katedry Świętojańskiej w latach 2006-2013, [w:] Opus temporis toruńskiej katedry historia najnowsza. Prace konserwatorskie restauratorskie w latach 2000-2013, red. K. Kluczwajd, ks. M. Rumiński, Toruń 2013, s. 49-84, przypis 5. oraz I. Brzostowska, Przyczynki do driejów budowlanych oraz wystroju malarskiego kościoła pw. sw. Jana Chrzciciela $i$ św. Jana Ewangelisty w Toruniu, [w:] Stare i nowe dziedzictwo Torunia, Torun 2013, s. 87-97.

12 A. Konieczny, Drieje budowy kościoła św. Jakuba w Toruniu w XIV wieku w świetle analiry architektonicznej, „Biuletyn Historii Sztuki”, 1, 2012, s. 5-32; L. Krantz-Domasłowska, Kościót sw. Jakuba w Toruniu - co nowego?, [w:] Stare i nowe dżiedzictwo Torunia, Toruń 2013, s. 41-57. 
tylko wspólnota miejsca i czasu łącząca je siecią wzajemnych kontaktów i nie tylko pragmatyka budowlana decydowały o wyborze tego wariantu korpusu. Miał on status formy dawnej o długiej metryce stylistycznie zróżnicowanych realizacji. Może ten właśnie walor był istotny, jeżeli przyjać, że Krzyżacy włączyli do swojej polityki artystycznych wyborów świadome nawiązania do form o romańskich koneksjach po to, by udokumentować własną historyczną tożsamość. Jeżeli w taki kontekst wpiszemy układ pseudobazylikowego wnętrza, innego zabarwienia nabierze zdecydowanie krytyczna ocena T. Mroczko, że „trwanie układu pseudobazylikowego w XIV i XV stuleciu było zjawiskiem anachronicznym", wyrazem regresu i niezrozumienia form gotyckich ${ }^{13}$.

Podobna architektoniczna retrospekcję dostrzec można w ukształtowaniu części zachodnich w wersji dwuwieżowych masywów w kościołach parafialnych Chełmna, Brodnicy (częściowo zrealizowany) oraz w katedrze w Chełmży i jednowieżowych z bocznymi aneksami, które występują w farach Torunia, Grudziądza, Chełmży. (il. 4) I chociaż jednostkowe filiacje przywoływane w literaturze dla poszczególnych obiektów różnią się, to wspólnym mianownikiem pozostają źródłowe odniesienia do architektury romańskiej. Tę wczesną tradycję utrwala stosowana terminologia. Występujące powszechnie w odniesieniu do fasad krzyżackich kościołów określenie masyw zachodni wynika z podstawowego oglądu, wizualnego skojarzenia z blokową strukturą, dopiero poszukiwanie źródeł prowadzi do właściwego prawzoru $^{14}$. Dzięki badaniom T. Mroczko, O. Asendorfa i A. Soćki dwuwieżowe masywy przywołanych kościołów wpisać można w uporządkowany chronologicznie i typologicznie szereg. Inicjuje go fasada kościoła farnego w Chełmnie zrealizowana w 1. ćw. XIV w. (z nieukończoną wieżą południowa), która zainspirowała twórców części zachodniej katedry w Chełmży, 1. poł. XIV w. oraz kościoła św. Katarzyny w Brodnicy, 1. poł. XIV

\footnotetext{
13 T. Mroczko, op. cit., s. 224.

14 „Masyw zachodni” (Westbau) jest określeniem powszechnie stosowanym w odniesieniu do części zachodniej niezależnie od układu rzutu i bryły z wieża/wieżami jako kompozycyjną dominanta. Jego początki wiążą się z rozwiązaniami karolińsko-ottońskimi, które następnie ulegały różnorodnym zmianom i modyfikacjom zarówno pod względem formy, jak i funkcji. D. von Schönfeld de Reyes, Wetwerprobleme: zur Bedeutung der Westwerke in der Kunsthistorischen Forschung, Weimar 1999.
} 
w. (ze zrealizowaną jedynie wieżą południowa) $)^{15}$. (il. 5, 6) $\mathrm{O}$ znaczeniu chełmińskiego przykładu i stojącej za nim tradycji świadczy odwołanie się do niego jako wzorca w dokumencie fundacyjnym katedry w Królewcu z 1333 roku $^{16}$. Dla uwypuklenia wątków romańskich odniesień w architekturze krzyżackiej istotne znaczenie mają ustalenia A. Soćki, który w kamiennym masywie nadreńskiej kolegiaty św. Wiktora w Xanten (2. poł. XII w.) dostrzegł formalny pierwowzór dla wież kościoła Mariackiego w Chełm$n^{1}{ }^{17}$. Osadzony mocno w realiach analizy porównawczej wywód zawiera istotne wskazanie. Szukając przyczyn tych odległych chronologicznie inspiracji, autor wskazuje między innymi na uwarunkowania ideowe, status kolegiaty w strukturze diecezji kolońskiej oraz rangę kościoła martyrialnego związana z wezwaniem św. Wiktora i jego wczesnochrześcijańskimi korzeniami. Można założyć, że wybór formy masywu zachodniego w kolegiacie w Xanten i farze chełmińskiej sięgał do tego samego rdzenia, do myślenia o architekturze jako formie historycznego przekazu.

Czy podobne odwołania do przeszłości możemy odnaleźć także w wariancie jednowieżowym? Tutaj fary w Chełmży, Grudziądzu, nowomiejska w Toruniu oraz staromiejska św. Jana (być może już na etapie II kościoła) prezentują układ wieży wpisanej w korpus nawowy i powiązanej z bocznymi aneksami będącymi przedłużeniem naw bocznych. (il. 7, 8, 9, 10, 11) Wizualnie tworzą wyraźną cezurę w bryle kościoła, ale niższe partie boczne nie daja tak całościowego efektu zwartego bloku jak wariant dwuwieżowy. Niemniej w swojej genezie także sięgaja do tradycji romańskiego masywu zachodniego, o czym pisał już M. Kutzner, szukając analogii dla zachodniej części kościoła św. Jakuba na terenach Meklemburgii i Brandenburgii, oraz T. Mroczko, uwzględniając jeszcze XIII-wieczną tradycję architektury

15 Szczegółowe datacje u poszczególnych autorów różnią się tym bardziej, że proces budowy postępował najczęściej etapowo. Ponadto nie zawsze ukończono obie wieże, w Chełmnie zbudowano jedynie północna, a w Brodnicy południowa. T. Mroczko, op. cit., s. 68, 125, 255; O. Asendorf, Mittelalterliche Türme im Deutschordensland Peussen. Untersuchungen zu ibrer Bedeutung und Funktion, Frankfurt/Main 1998, s. 179-185; A. Soćko, Układy emporowe..., s. 21-24, 128-129; 42-45; idem, Pierwow ź́r masywu..., s. 5-34.

${ }_{16}$ T. Mroczko, op. cit., s. 68; O. Asendorf, op. cit., s. 170. Jednocześnie jest to argument za uznaniem wieży północnej kościoła w Chełmnie za ukończoną w 1333 roku.

17 A. Soćko, Pierwowrór masymu... 
westfalskiej ${ }^{18}$. Genetycznym praźródłem dla jedno- i dwuwieżowych układów jest masyw zachodni, a więc i romanizujące odniesienia są jednakowo prawomocne.

Wieża to element budowli sakralnej najmocniej nasycony znaczeniem ${ }^{19}$. Wspomniane masywy zachodnie krzyżackich kościołów miały kondygnację empor wizualnie i funkcjonalnie powiązaną $z$ wnętrzem korpusu. One także stanowia przykład świadomej archaizacji i nawiązań do wnętrz o patronackich i władczych funkcjach usytuowanych na górnych kondygnacjach zgodnie $z$ archetypiczna zasadą hierarchizacji przestrzeni ${ }^{20}$.

Przywołane tu architektoniczne przykłady, a właściwie wyabstrahowane fragmenty budowli sakralnych, w tradycyjnej formalnej analizie porównawczej są często określane jako rozwiązania stylistycznie zapóźnione i zaliczane do cech regresywnych architektury krzyżackiej. Uzasadniając ich obecność, zwracano uwagę na obiektywne uwarunkowania, mnogość źródeł będących konsekwencją mobilności Krzyżaków, ich licznych kontaktów szczególnie z obszarem Cesarstwa nasyconym budowlami romańskimi ${ }^{21}$. W tej konkretnej sytuacji, gdy mówimy o tradycjonalizmie, momentem kluczowym jest konstruktywna decyzja, a nie mechaniczne powielanie utrwalonych schematów. Predylekcję do form romańskich można więc postrzegać jako wartość, w kategoriach świadomego wyboru określonej opcji stylistycznej, satysfakcjonującej artystycznie i funkcjonalnie, ale przede wszystkim kojarzacej się z historycznie rozumiana „dawnością”. Te historycznie motywowane odniesienia pozwalały nasycić ziemię pozbawioną własnej tożsamo-

18 T. Mroczko, op. cit., s. 185; M. Kutzner, op. cit., s. 67, 68. Jako najbliższy dla sposobu opracowania elewacji wieży kościoła św. Jakuba w Toruniu przywołuje kościół św. Mikołaja w Brandenburgu.

19 Kompozycyjnie wieże wyznaczają główne akcenty w panoramie miasta, odzwierciedlając układ sił. Krzyżacy, mając świadomość tych odniesień, niekiedy ingerowali w sposób i wysokość realizowanych masywów wieżowych, o czym świadczy historia budowy kościoła św. Jana w Gdańsku, św. Mikołaja w Tallinie, katedry w Królewcu. O. Asendorf, op. cit., s. 7.

${ }^{20}$ Problem empor w architekturze krzyżackiej szczegółowo omówił A. Soćko, Układy emporowe... Ciekawą interpretację części zachodniej kościoła św. Katarzyny w Brodnicy powiązana z funkcjami relikwiowo-pielgrzymkowymi zaproponował J. Adamski w artykule Inspiracje sztuka dworska w państwie zakonnym w Prusach $i$ na Warmï. Katedra we Fromborku i fara w Brodnicy (w druku).

${ }^{21}$ T. Mroczko, op. cit., s. 319; A. Soćko, Romańskie tradycje..., s. 105. 
ści artystycznej budowlami, w których tkwił silny element tradycji. W ten sposób materializowały się aspiracje państwa krzyżackiego, którego celem było przekształcić obszar sobie podległy w terra christianitas. Romański modus budowli stanowił także zrozumiały przekaz dla osób „z zewnątrz”. Podobne przesłanie otrzymywał architekt, który realizował je, bazując na własnych doświadczeniach i wizualnej wiedzy.

\section{Summary}

\section{Reference to the past in the sacral architecture of the State of the Teutonic Order}

This paper is concerning the question of the presence of Romanesque provenance forms in the sacral architecture of the State of Teutonic order in Prussia. To depict the retrospective tendencies a typological category was used - a pseudo-basilica spatial disposition of the nave. Amongst over a dozen of churches representing such solution, often it is one of the stages of a longer erection process (Dzierzgoń, Bartoszyce, Nowe Miasto Lubawskie, the Franciscan church in Chełmno, or the parish church in Chełmża), there are some examples when this spatial variant was chosen as a desired form what can be classified as a deliberate reference to the Romanesque forms (the cathedral church in Kwidzyn, St. Nicolas church in Grudziądz, the project of St. Jacobs church in Toruń). The other elements of architectural retrospection can be seen in the shape of western, two tower fronts (parish churches in Chelmno, Brodnica, the cathedral in Chełmża), as well as the one tower fronts (parish churches in Toruń, Grudziądz, Chełmża) and the presence of galleries as excluded spaces for Teutonic hierarchs. Single affiliations quoted in the literature for certain objects are different but the common ground that remains in the Romanesque source for the references in architecture. It seems that the predilection for the forms of Romanesque context should be regarded as a conscious choice of a certain architectural narration with its source in ideological and historical function of these references. The Teutonic investors, acting on a ground deprived of artistic identity, were forced to create it from scratch. The Romanesque modus of the building gave this ahistorical space a certain feel of a "distant past". 


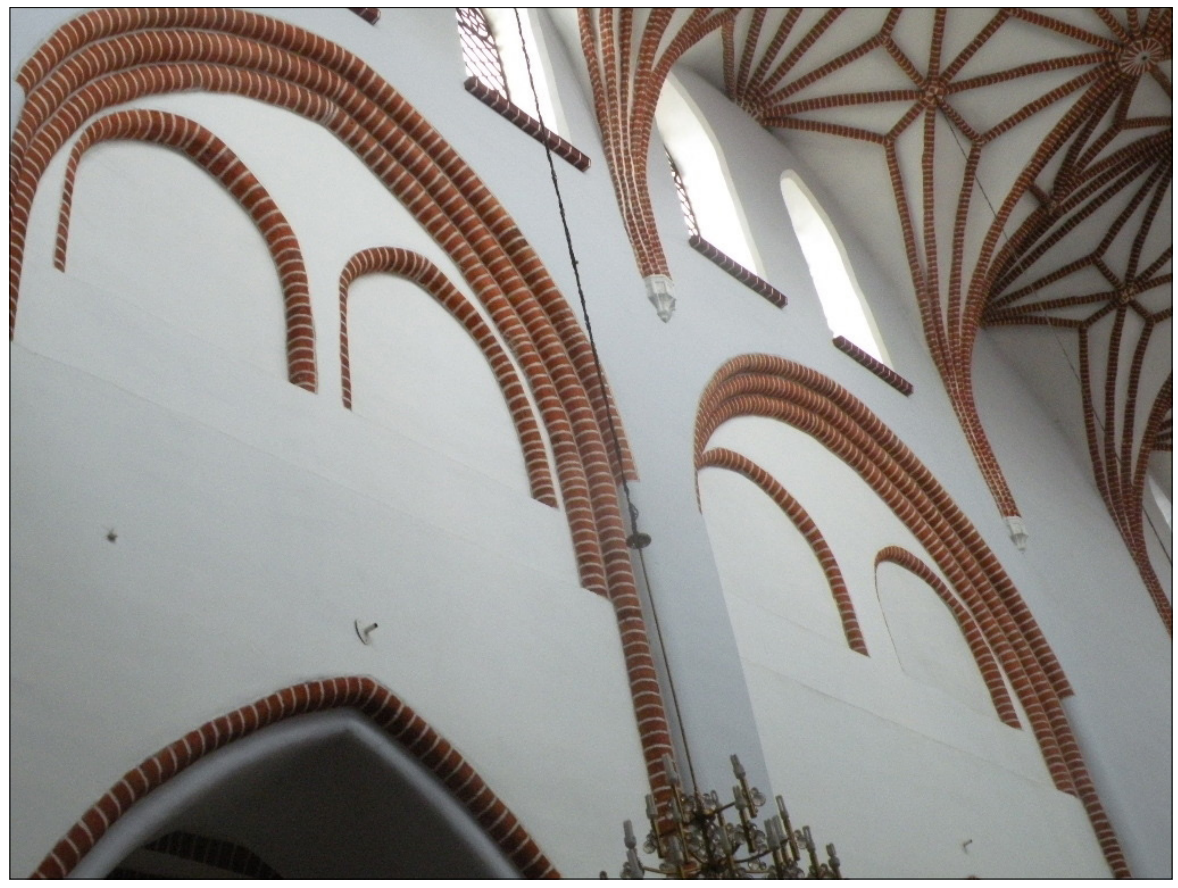

Il. 1. Bartoszyce, kościół parafialny św. Jana Ewangelisty, ściana międzynawowa, fot. J. Jakutowicz, http://www.kolomedievi.umk.pl 


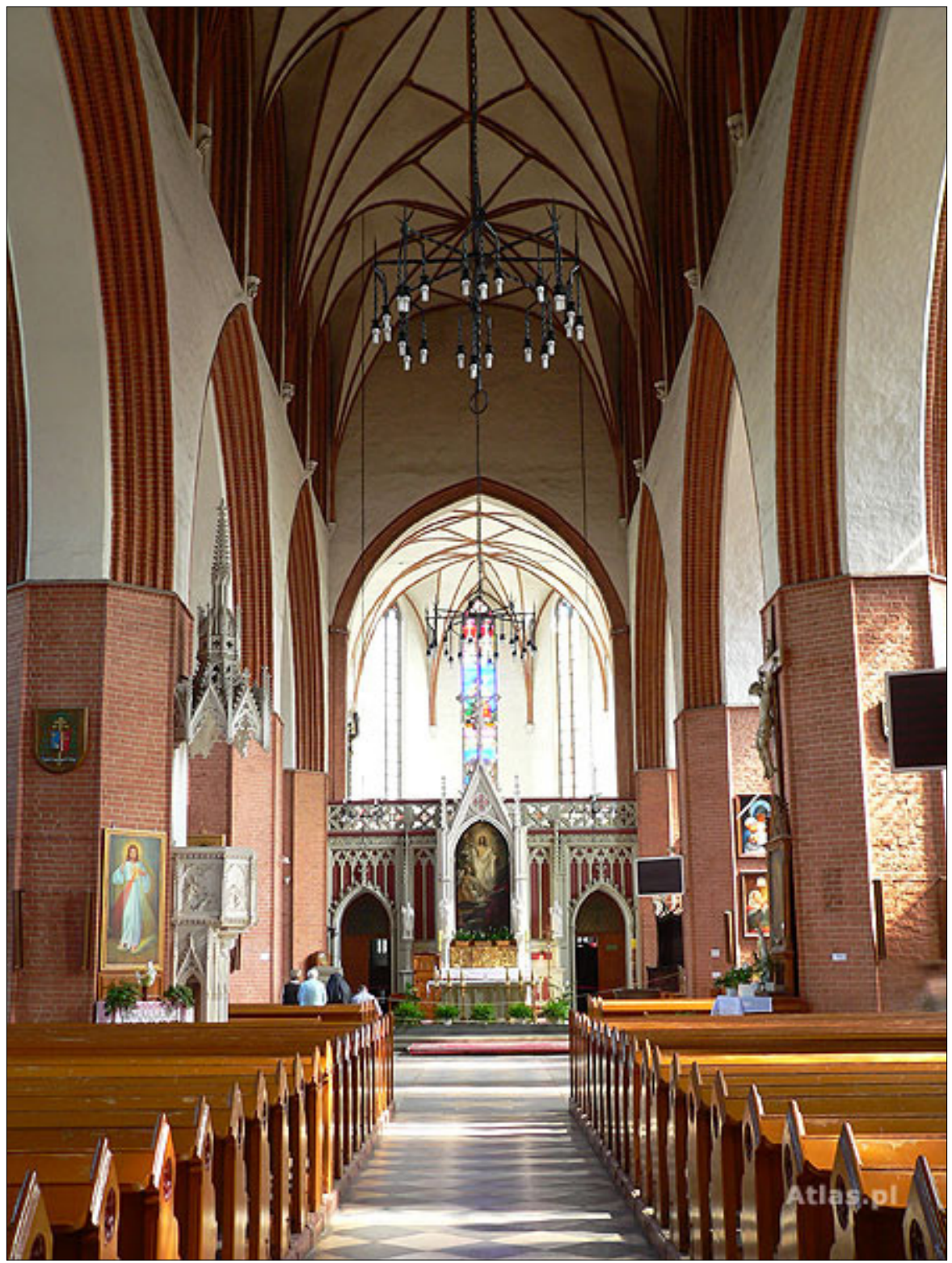

Il. 2. Kwidzyn, katedra NMP i św. Jana Ewangelisty, http://www.atlas.pl/kwidzyn_katedra-jana-ewangelisty-nawa-glowna.html (29.09.2013) 


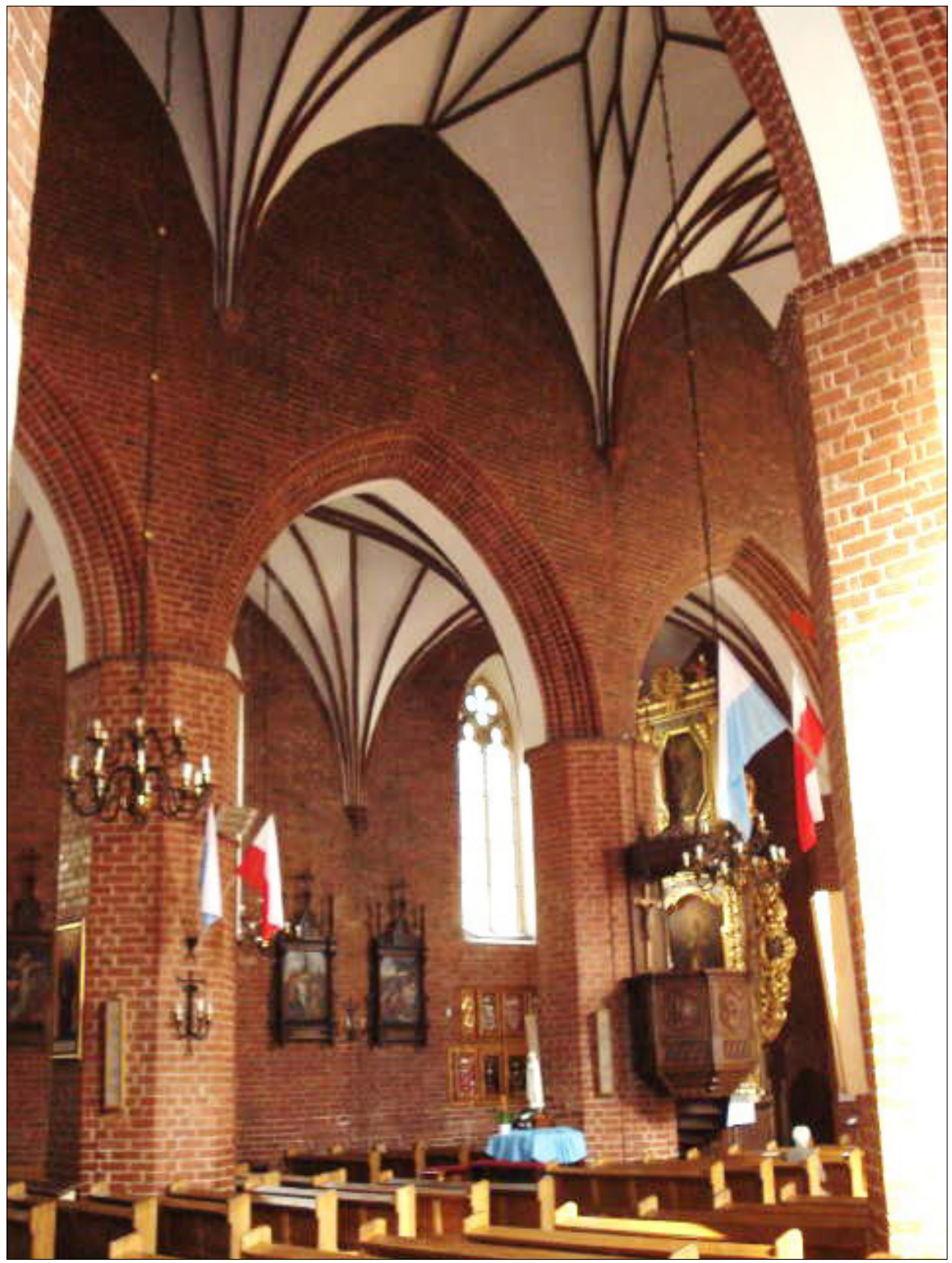

Il. 3. Grudziądz, kościół parafialny św. Mikołaja, wnętrze, fot. L. Krantz-Domasłowska 
a

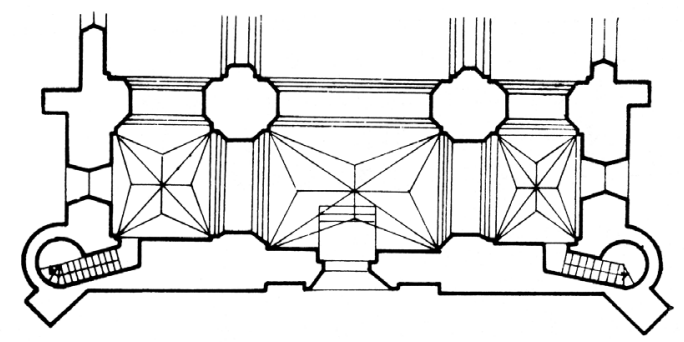

b
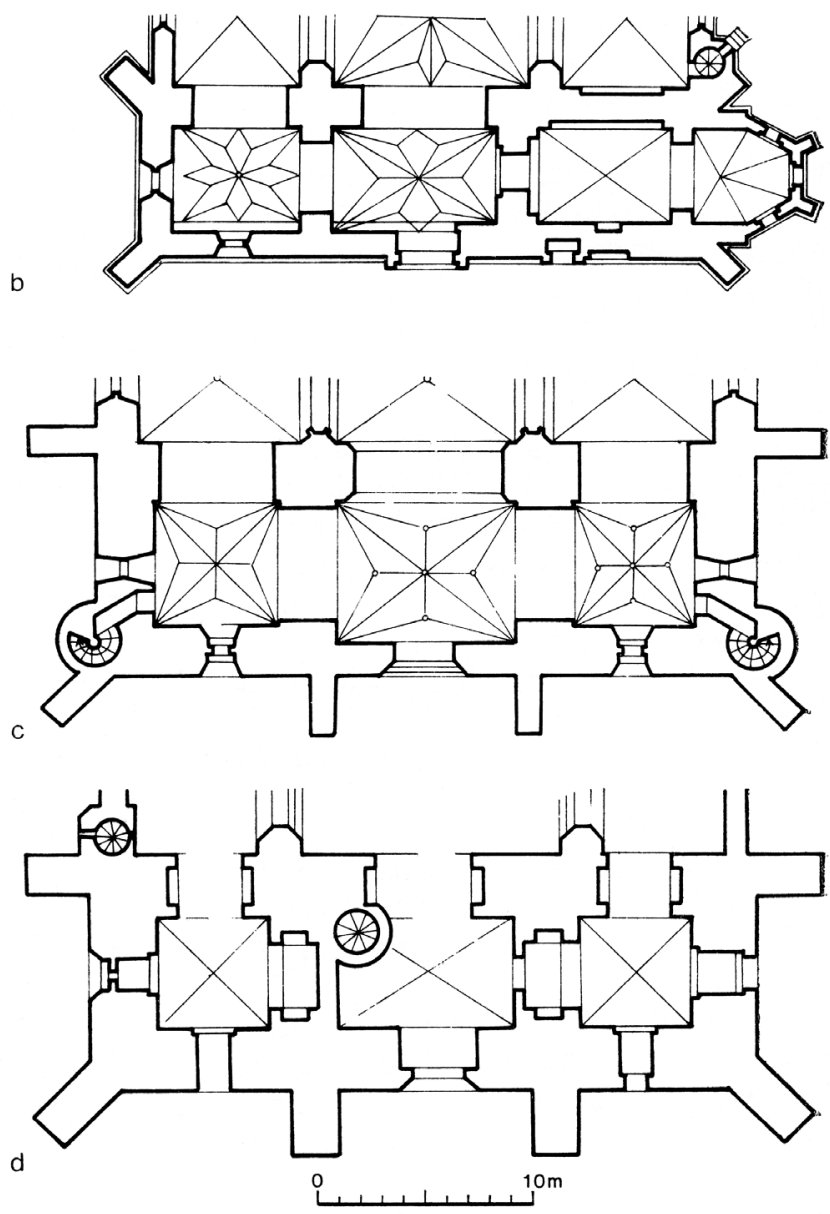

Il. 4. Rzuty masywów zachodnich dwuwieżowych: a/ katedry w Chełmży; b/ kościoła św. Katarzyny w Brodnicy; c/kościoła NMP w Chełmnie; d/ katedry w Królewcu, T. Mroczko, Arcbitektura gotycka na ziemi chetmińnskiej, Warszawa 1980, s. 67 


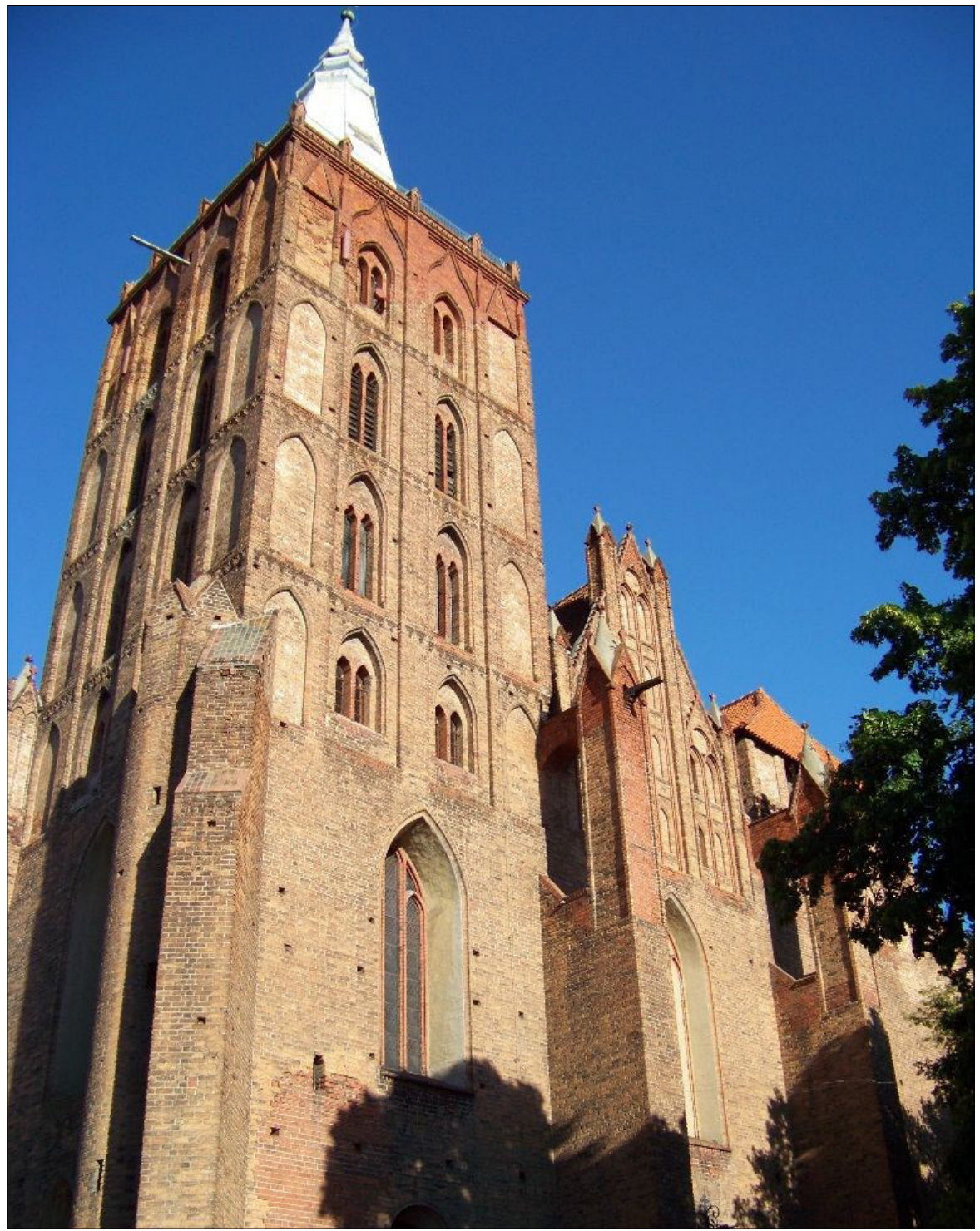

Il. 5. Chełmno, kościół parafialny NMP, fasada zachodnia 


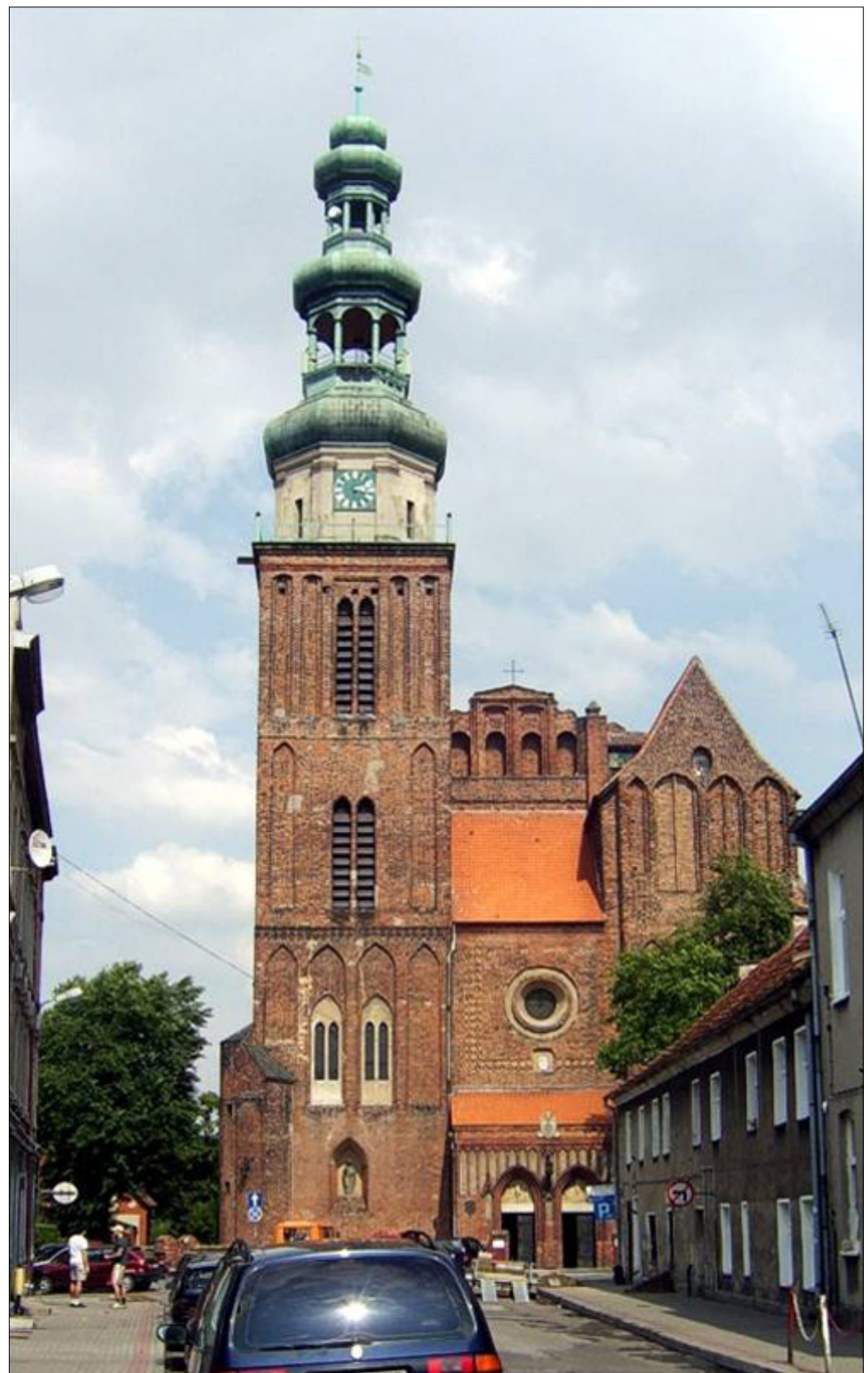

Il. 6. Chełmża, katedra fasada zachodnia, http://www.potrawyregionalne.pl (1.06.2014) 
[86]

a

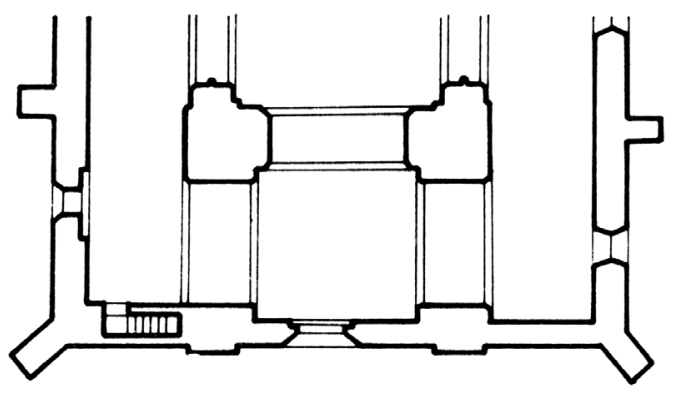

b
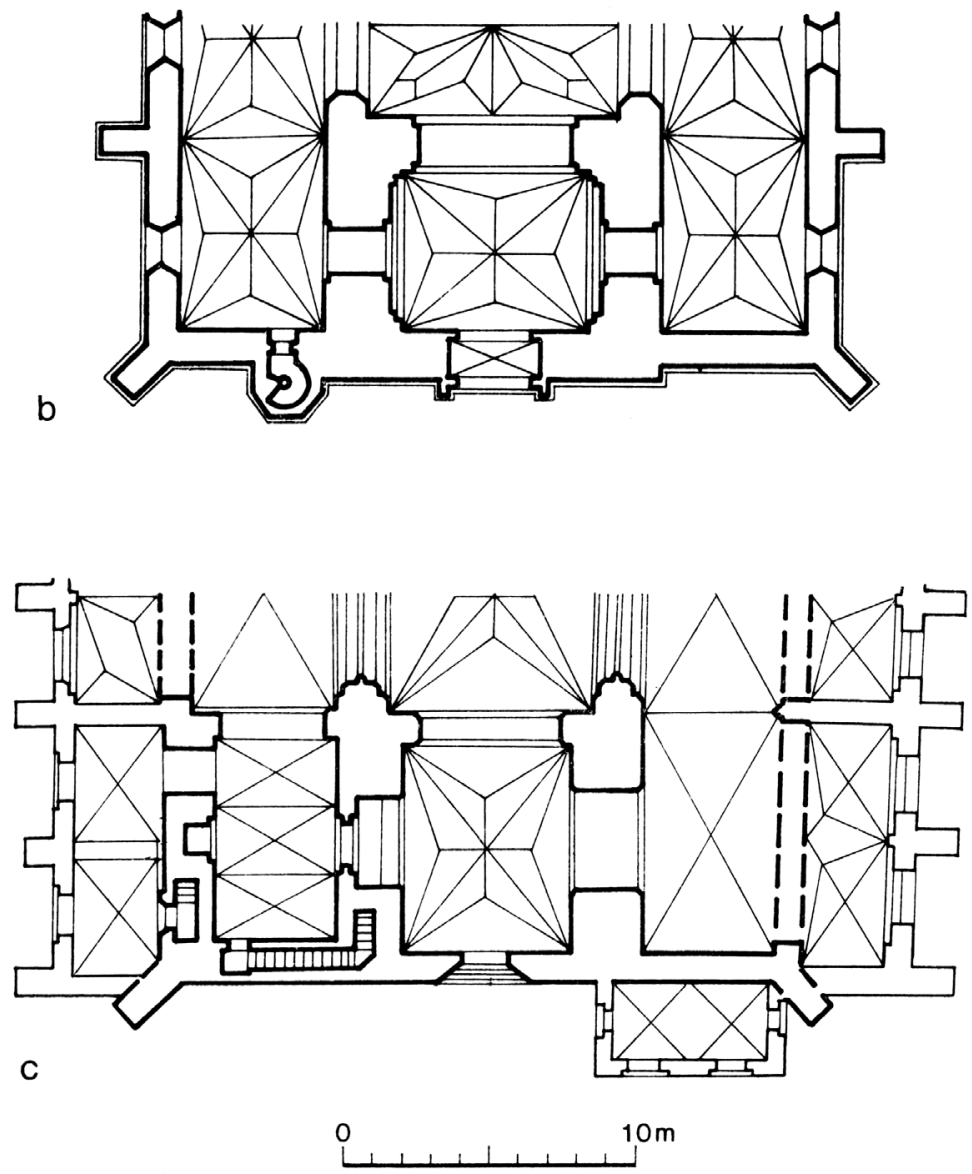

Il. 7. Rzuty masywów zachodnich jednowieżowych: a/ kościoła św. Mikołaja w Chełmży; b/ kościoła św. Mikołaja w Grudziądzu; c/ kościoła św. Jakuba w Toruniu, T. Mroczko, Architektura gotycka na ziemi chetminskiej, Warszawa 1980, s. 189 


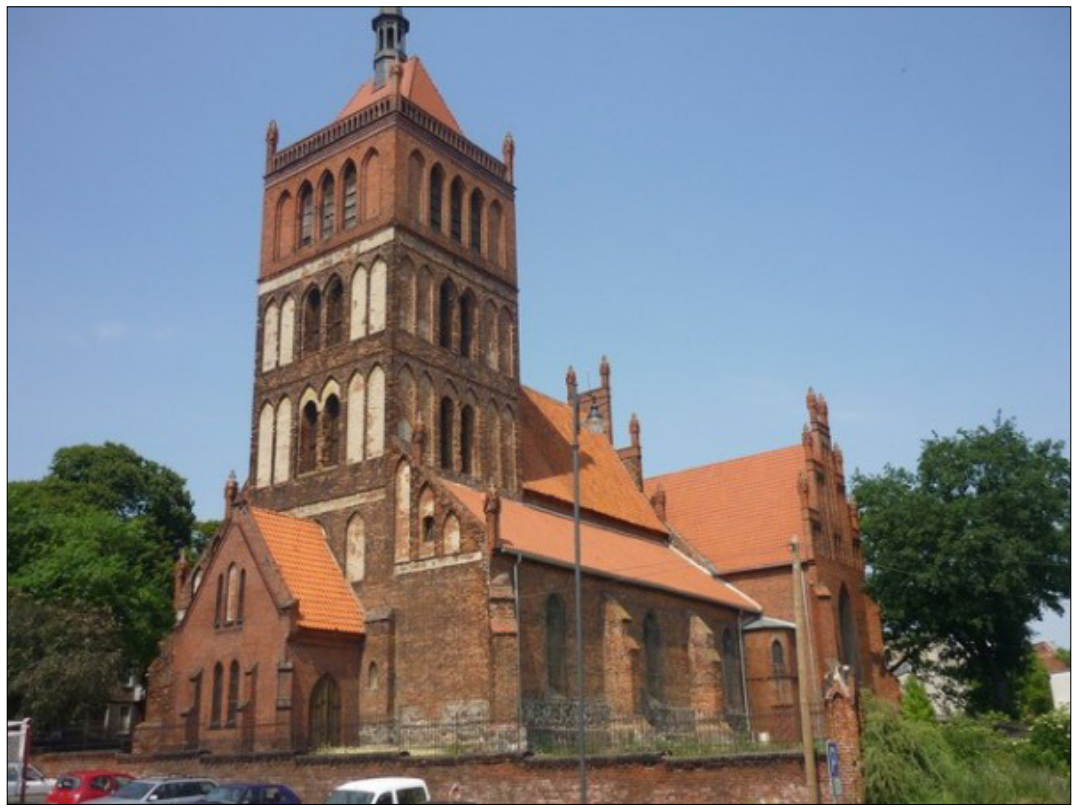

Il. 8. Chełmża, kościół parafialny św. Mikołaja, fasada zachodnia, http://karolxii. bikests.pl (1.06.2014)

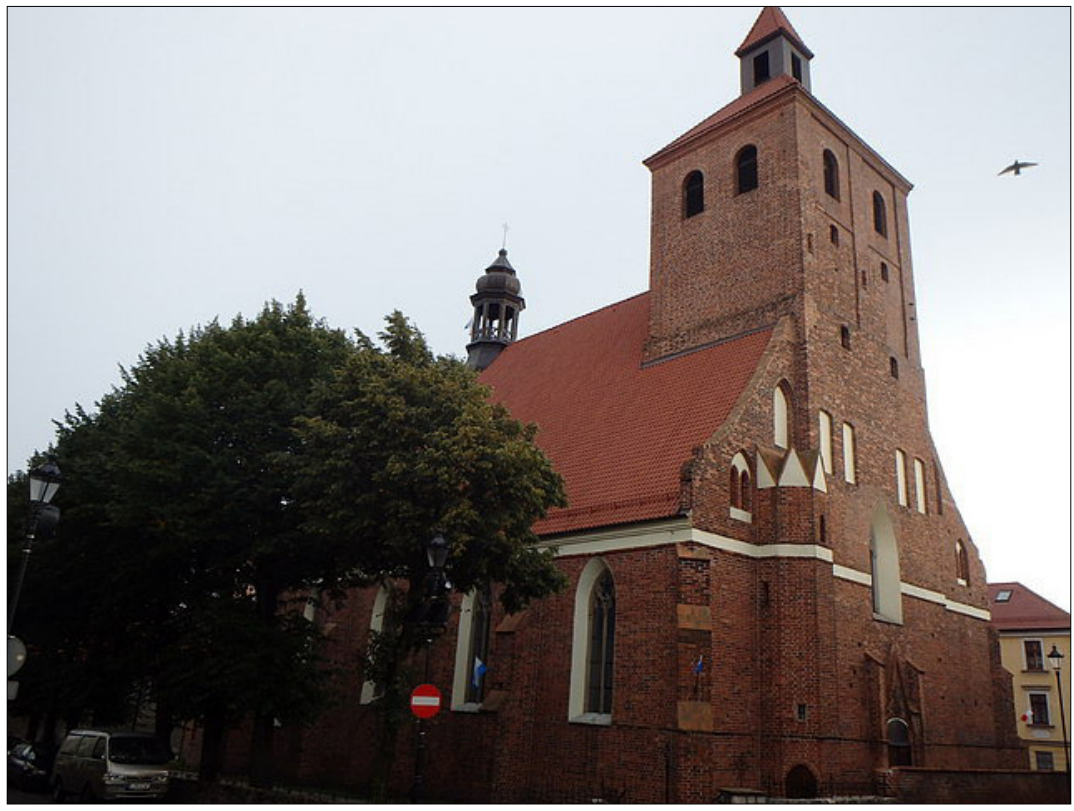

Il. 9. Grudziądz, kościół parafialny św. Mikołaja, masyw zachodni, fot. L. Krantz-Domasłowska. 
[88]

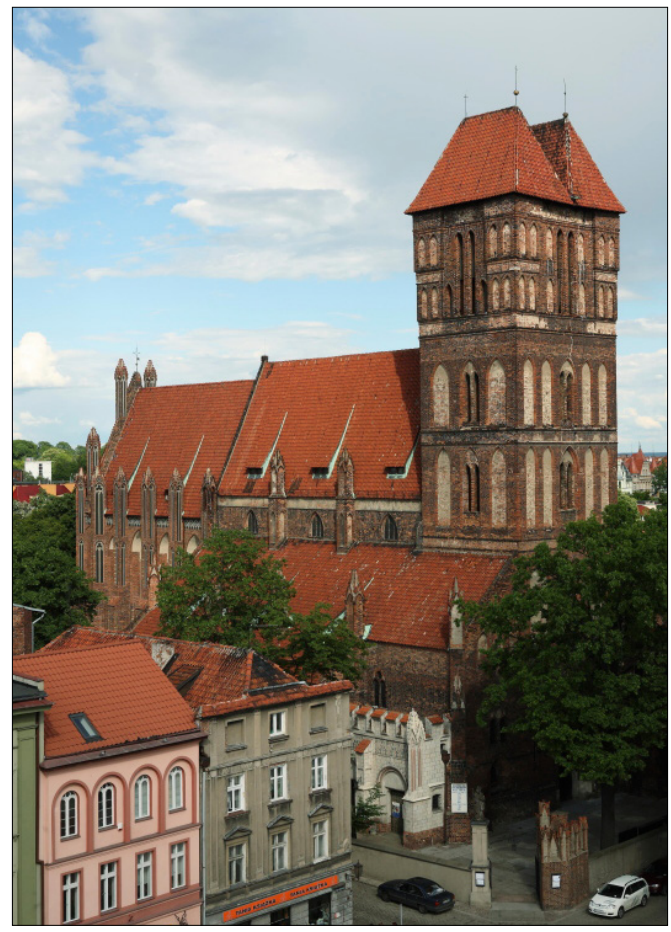

Il. 10. Toruń, kościół św. Jakuba, bryła, fot. A. Skowroński

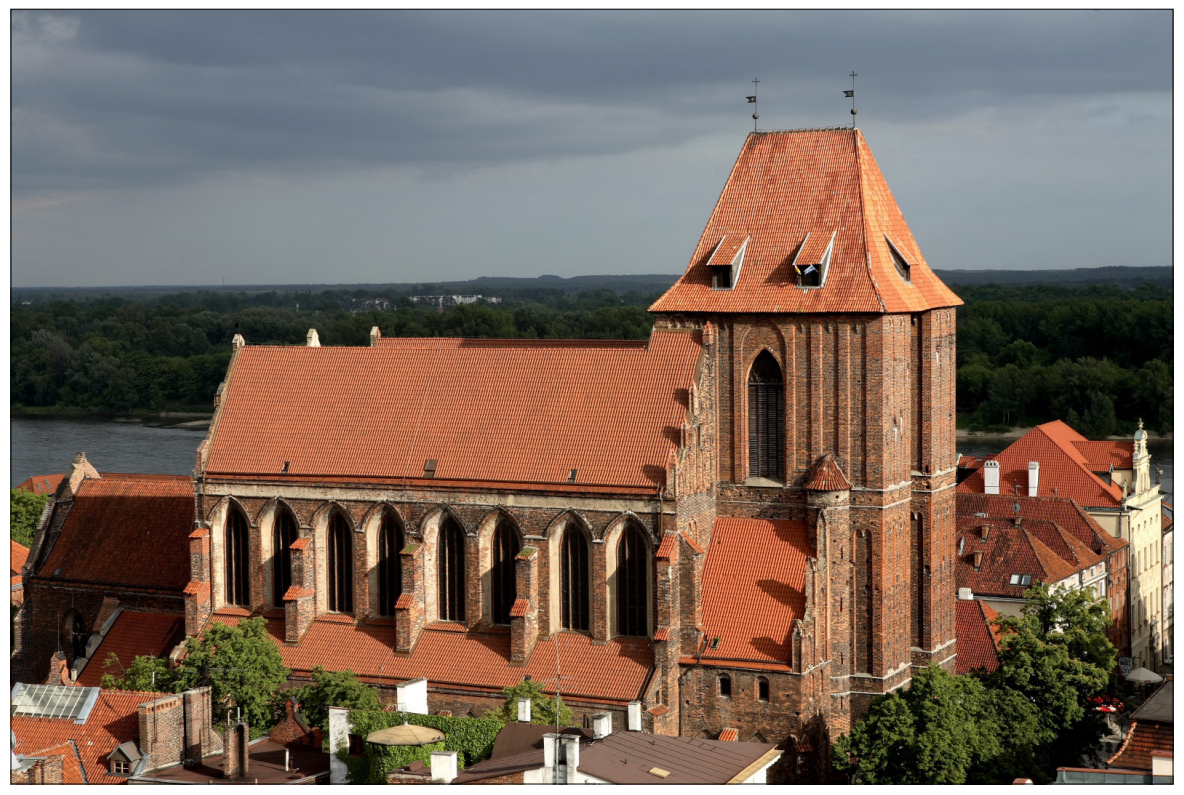

Il. 11. Toruń, kościół św. Jana, fot. A. Skowroński 